\title{
Early Palaeogene planktic foraminiferal and carbon isotope stratigraphy, Hole 762C, Exmouth Plateau, northwest Australian margin
}

\author{
HAIDI J. L. HANCOCK ${ }^{1}$, GEORGE C. CHAPRONIERE ${ }^{2}$, GERALD R. DICKENS ${ }^{3}$ \& ROBERT A. HENDERSON ${ }^{1}$ \\ ${ }^{1}$ School of Earth Sciences, James Cook University, Townsville QLD 4811, Australia (e-mail: Haidi.Hancock@jcu.edu.au). \\ ${ }^{2}$ Department of Geology, Australian National University, Canberra ACT 0200, Australia. \\ ${ }^{3}$ Department of Earth Science, Rice University, Houston, TX 77005-1892, USA.
}

\begin{abstract}
Although the northwest margin of Australia is an important region for petroleum exploration and palaeoceanographic investigations, its Palaeogene stratigraphy is poorly documented, especially in terms of a foraminiferal biozonation. Early Palaeogene cores from 502.96 to $307.80 \mathrm{~m}$ below sea floor at Ocean Drilling Program Site 762 on the Exmouth Plateau were examined in this study for their planktic foraminiferal assemblages and the carbon isotopic compositions of Subbotina spp. Planktic foraminifera are generally well preserved and belong to 74 species and 17 genera. In spite of a mid-latitudinal palaeolatitude $\left(c .40^{\circ} \mathrm{S}\right)$ the sequence, deposited between the early Paleocene and Middle Eocene, contains all planktic foraminiferal Zones P1c through P10 of the current global scheme for tropical locations, except for Subzone P4b. Most zones are well defined by the datums of primary marker species except $\mathrm{P} 3 \mathrm{a}$ and $\mathrm{P} 9$, which have boundaries that probably occur in core gaps, and the P9 zonal boundaries are defined by secondary marker species. Overall, variations in $\delta^{13} \mathrm{C}$ based on sequential samples of Subbotina are similar in pattern and magnitude to global summary isotope curves spanning the early Palaeogene. However, the prominent $\delta^{13} \mathrm{C}$ excursion that characterizes the Palaeocene/Eocene transition is mostly missing and appears to lie in a core gap. The planktic foraminiferal zonation, linked with that based on nannofossils, a recalibrated magnetostratigraphy and carbon isotope records, provides a robust temporal framework for the Early Palaeogene of the northwest margin of Australia. J. Micropalaeontol. 21(1): 29-42, May 2002.
\end{abstract}

\section{INTRODUCTION}

The Early Palaeogene $c .65$ to $49 \mathrm{Ma}$ (Fig. 1) is an especially significant interval of time because of profound changes in climate, ecosystems and the global carbon cycle (e.g. Zachos et al., 1993, 2001; Corfield, 1994; Thomas \& Shackleton, 1996; Dickens et al., 1997; Norris \& Röhl, 1999). Indeed, documentation of Palaeogene paleoceanography is now a high priority for stratigraphic research. However, to resolve outstanding questions of global change, early Palaeogene marine successions must be located that meet certain criteria. These targets must be: (1) thick so as to maximize the temporal quality of the record and time resolution; (2) buried with little overburden to reduce the logistical demands of drilling and diagenetic effects; (3) rich in well-preserved biogenic carbonate for geochemical evaluation; and (4) hosted in stratal geometries which permit construction of detailed depth and latitudinal transects. To date, one of the few investigated locations which meets these criteria is the recently drilled Blake Nose in the western North Atlantic. Studies of this region have already advanced our knowledge of Palaeogene environmental change significantly (e.g. Bains et al., 1999; Katz et al., 1999; Norris et al., 1999; Norris \& Röhl, 1999).

The Exmouth Plateau (Fig. 2) is a submerged platform extending $150-500 \mathrm{~km}$ off northwest Australia that consists of thinned and tilted continental crust with a Phanerozoic sedimentary sequence exceeding $10 \mathrm{~km}$ (Barber, 1988; Stagg \& Colwell, 1994). The stratigraphic succession on the plateau is particularly significant because it contains a somewhat expanded Palaeogene sequence deposited in moderate water depths and within the southern subtropical zone (Exon et al., 1992). Moreover, unlike many other regions in the world, the Exmouth Plateau has extensive seismic coverage because of petroleum exploration. Seismic records indicate a substantial Palaeogene record which includes thick successions in both offshore and inshore locations making the Exmouth Plateau a potential location for detailed Palaeogene oceanographic reconstructions.

Current understanding of Palaeogene stratigraphy for the northwest margin of Australia is mostly a conglomeration of data from sidewall cores and ditch-cuttings largely held outside of the public domain. Ocean Drilling Program (ODP) Sites 762 and 763 were drilled by Leg 122 in 1988 on the Exmouth Plateau in part to provide an accessible stratigraphic framework for the Tertiary and Cretaceous. Although Neogene and Cretaceous intervals are now well documented for these sites (Wonders, 1992; Zachiariasse, 1992), other than the ranges of calcareous nannofossils (Siesser \& Bralower, 1992), and analyses of bulk carbonate carbon isotopes (Thomas et al., 1992), the Palaeogene stratigraphic record has been given little attention. Planktic foraminifera have not been rigorously examined, carbon isotopes have not been measured on foraminiferal species or calibrated against other time markers, and the interpretation of polarity chrons (Galbrun, 1992) is inconsistent with the nannofossil stratigraphy (Siesser \& Bralower, 1992). Moreover, the timescale used in previous work (Shipboard Scientific Party, 1990) is now outdated, precluding direct age comparisons with other regions. This study addresses these deficiencies by examining planktic foraminifera and their isotopic composition in sediment from ODP Site 762. The new dataset is combined with the results of previous studies to construct the first detailed early Palaeogene record for the Exmouth Plateau. 


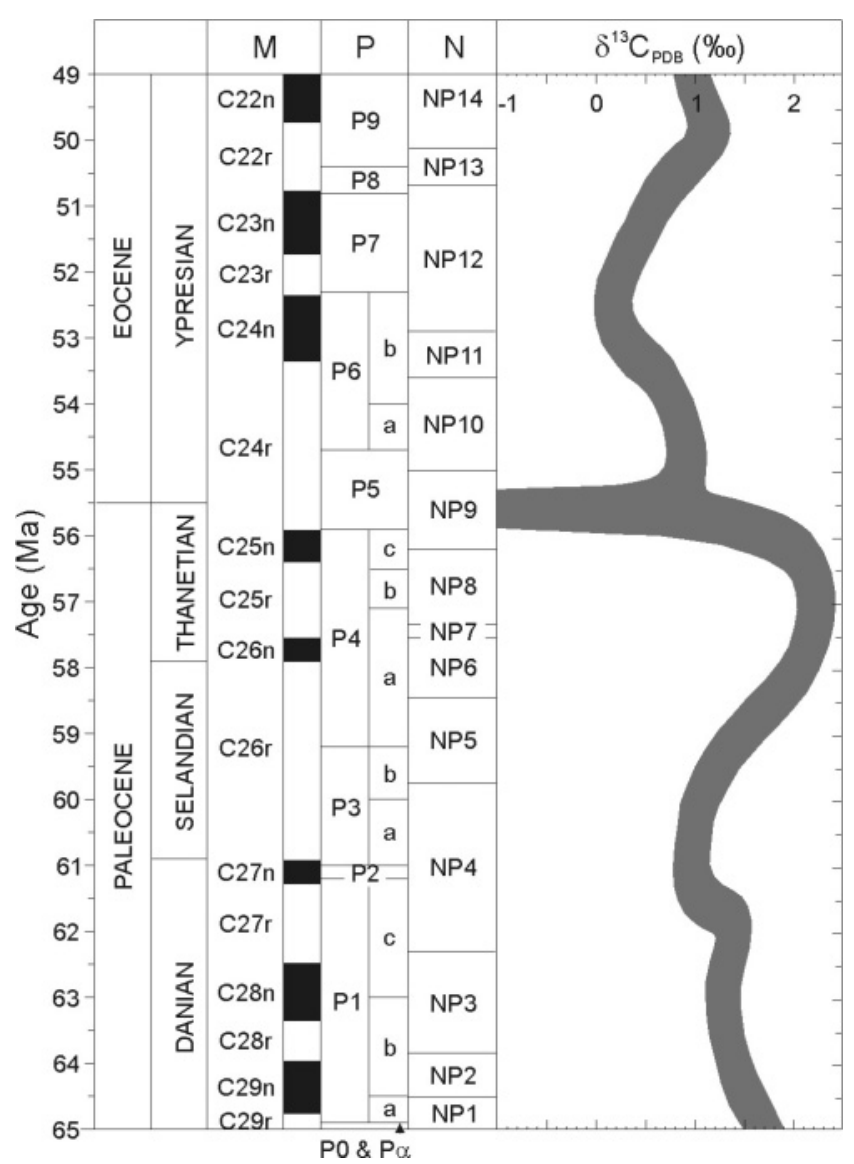

Fig. 1. Early Palaeogene global stratigraphy including magnetostratigraphy $(\mathrm{M})$, planktic foraminifera $(\mathrm{P})$ and nannofossil biozones $(\mathrm{N})$ (adapted from Berggren et al., 1995) and the global benthic foraminifera carbon isotope curve (adapted from Shackleton \& Hall, 1990 and Zachos et al., 2001).

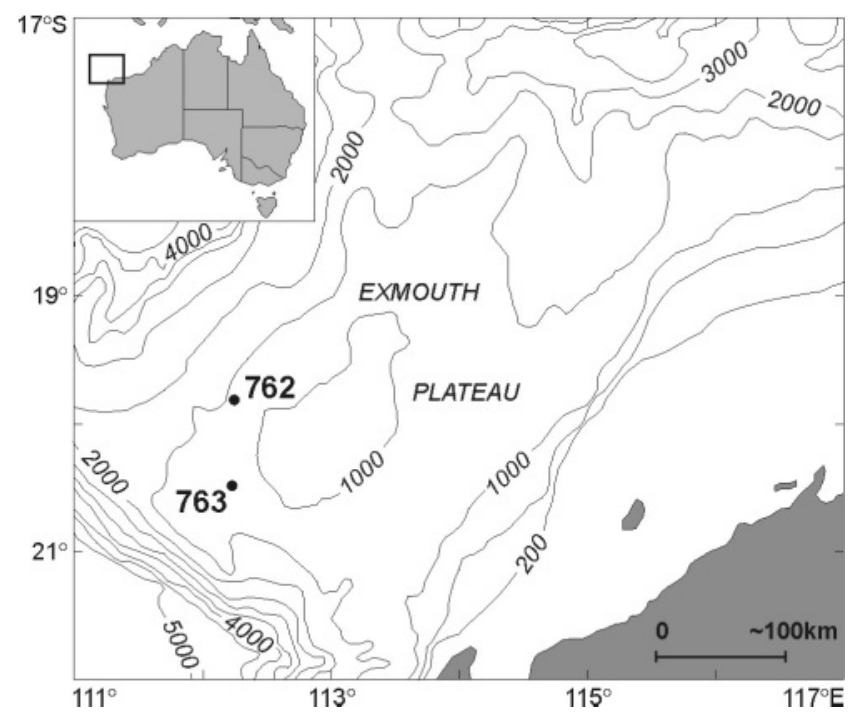

Fig. 2. Map of the Exmouth Plateau including ODP Sites 762 and 763 of Leg 122 (adapted from Exon et al., 1992). Bathymetry in metres.

\section{MATERIALS AND METHODS}

\section{Samples}

Ocean Drilling Program Hole $762 \mathrm{C}$ (Fig. 2) was drilled on the central Exmouth Plateau (19 $\left.53.24^{\prime} \mathrm{S}, 112^{\circ} 15.24^{\prime} \mathrm{E}\right)$ in $1360 \mathrm{~m}$ of water depth. Preliminary shipboard work (Shipboard Scientific Party, 1990) and shore-based nannofossil investigations (Siesser \& Bralower, 1992) documented 550 m of Middle Eocene to Lower Campanian nannofossil chalks and oozes from the recovered core. This study investigates 83 samples taken from some $200 \mathrm{~m}$ of sediment deposited between the late Early Palaeocene and the early to Middle Eocene. Bulk sediment in this interval consists predominantly of white to pale yellow (5Y $8 / 2$ ) or grey green $(10 \mathrm{YR} 8 / 1)$ carbonate ooze and chalk.

Individual samples of $c .20 \mathrm{~g}$ were collected at $c .1 .5 \mathrm{~m}$ intervals from cores $762 \mathrm{C}-16 \mathrm{X}-4$ to $-37 \mathrm{X}-4$ (307.5 to $503.5 \mathrm{~m}$ below sea floor (mbsf)). Portions of each sample were processed for microfossils at the Australian Geological Survey Organization (AGSO) palaeontological laboratory. These samples were treated with hydrogen peroxide to remove organic matter, sieved to remove the $<63 \mu \mathrm{m}$ fraction, and stored in glass vials. The residues were picked for planktic foraminifera, either to completion or to obtain a complete record of taxonomic content. At least 200 and upwards of 500 specimens from each sample were separated and examined as representative of the faunal record.

\section{Biostratigraphy}

The identity, relative abundance of individual foraminiferal species, and distribution across the sample set from Site 762 were determined by optical microscopy and scanning electron microscope. Relative abundances of species were classified as dominant $(\mathrm{D},>30 \%)$, common $(\mathrm{C}, 10$ to $30 \%)$, rare $(\mathrm{R}, 2$ to $10 \%$ ) and extremely rare $(\mathrm{X},<2 \%)$. Most specimens belong to the genus Acarinina (A), Subbotina $(S)$, Morozovella $(M)$, Globanomalina $(G)$, Chiloguembelina $(C)$ or Parasubbotina $(P)$. The preservation state of the tests also was noted as 'poor', 'moderate' or 'good'. Tests with good preservation show minor secondary calcite growth or dissolution. Tests with moderate preservation are often infilled with calcite or fragmented, but can be classified to species. Tests with poor preservation are moderately to heavily encrusted with secondary calcite, and species identification is less certain.

The current planktic foraminiferal zonal scheme by Berggren et al. (1995) is used in this study. Although Site 762 was at southern mid-latitudes $\left(c .40^{\circ}\right)$ during the Palaeogene (Veevers et al., 1991; Clarke \& Jenkyns, 1999), the low latitude biozonation scheme by Berggren et al. (1995) best describes the observed faunal assemblages. Palaeocene foraminiferal classification, including ranges and zonal boundaries, has been summarized recently by Olsson et al. (1999). Boundaries between biozones were placed halfway between the sample containing a defining marker species and the sample above or below it that lacks it.

\section{Stable isotopes}

Specimens of Subbotina were separated and analysed for their carbon isotope composition. Although Subbotina probably inhabited deep surface waters in the thermocline (Berggren \& Norris, 1997) this genus is considered especially appropriate for 
such work because carbon isotope composition shows little inter-species variation (Berggren \& Norris, 1997) and sizerelated variation (D'Hondt et al., 1994; Norris, 1996). However, as an added precaution to minimize the effect of ontogenetic changes in depth ecology, we restricted the size range of tests (210 to $260 \mu \mathrm{m}$ diameter) and collected 20-30 specimens for each analysis. Although no single Subbotina species spanned the entire early Palaeogene, species with suspected phylogenetic affinities (Olsson et al., 1999) and similar morphologies within the genus were collected. The species collected for isotope analyses were $S$. triloculinoides (Zone P1c to the middle of Subzone P4a-b), S. triangularis (Subzone P4a/b to Subzone P6a) and S. patagonica (Subzone P6a to Zone P10).

Stable isotopes were analysed at the isotope laboratory in the Earth Science Board at the University of California, Santa Cruz (see Billups et al., 1998). Samples were subjected to ultrasound whilst bathed in methanol for 3-5 s to remove adhering particles. Samples then were reacted at $90^{\circ} \mathrm{C}$ in $\mathrm{H}_{3} \mathrm{PO}_{4}$ on an autocarb common acid bath with the $\mathrm{CO}_{2}$ generated then analysed in a Prism gas source mass spectrometer. Carbon isotope values were calibrated to the Peedee belemnite (PDB) standard, and converted to conventional delta notation $\left(\delta^{13} \mathrm{C}\right)$.

\section{RESULTS AND DISCUSSION}

\section{Foraminiferal biostratigraphy}

Planktic foraminifera contribute between $10 \%$ and $20 \%$ of bulk sample volume. The planktic to benthic foraminiferal ratio for the early Palaeogene is approximately 15:1 and the benthic foraminiferal component rarely exceeds $2 \%$. Microfossils are generally complete and unabraded. Secondary recrystallization or dissolution hampers the identification of species in only a few intervals (Fig. 3), notably within the foraminiferal biozones P4 and P7 (discussed below).

Some 74 species belonging to 17 genera were identified at Site 762, and established biozones can be recognized from the pattern of faunal succession (Figs. 3, 4). All zones from P1c to P10, with the exception of Subzone P4b, are found at Site 762, spanning the interval from the early Palaeocene (Danian) to the early Middle Eocene (early Lutetian). Absolute age assignments are from Berggren et al. (1995). Boundaries between different zones are well defined unless noted otherwise. The zonal scheme adopted here generally follows that of Berggren et al. (1995) but some modification is required.

P1c. FAD of Globanomalina compressa and/or Praemurica inconstans to FAD of Praemurica uncinata (500.72 mbsf). Age: 63.0-61.2 Ma, early Palaeocene (Danian). Subzone P1c extends below our sampled interval as only two samples are representative of it. The upper boundary of Subzone P1c is difficult to locate in some sequences because of the short stratigraphic range of its marker species, Pr. uncinata (Pl. 1, figs 1-3). However, this species has been found at Site 762, and is a useful correlation tool. Common species found in uppermost Subzone P1c include Pr. pseudoinconstans, Parasubbotina varianta, Subbotina trivialis, S. triloculinoides, Globanomalina compressa, Chiloguembelina midwayensis and C. subtriangularis. Faunal assemblages within this subzone are consistent with the global scheme (Olsson et al., 1999).
P2. FAD of Praemurica uncinata (500.72 mbsf) to FAD of Morozovella angulata (493.33 mbsf). Age: 61.2-61.0 Ma, late Early Palaeocene (late Danian). Site 762 contains the transition from Praemurica inconstans/trinidadensis to Pr. uncinata, which marks the lower zonal boundary. However, an $8 \mathrm{~m}$ core gap between cores $-37 \mathrm{X}-1$ and $-36 \mathrm{X}-1$ below the FAD of Morozovella angulata ( $\mathrm{Pl}$. 1, figs 4-6) precludes high resolution sampling and accurate placement for the upper boundary. Common species in this zone at Site 762 include Parasubbotina varianta, $P$. pseudobulloides, Subbotina triloculinoides, $S$. cancellata, Praemurica pseudoinconstans and Chiloguembelina midwayensis. This overall assemblage is typical of Zone P2 elsewhere (Olsson et al., 1999).

P3. FAD of Morozovella angulata (493.33 mbsf) to FAD of Globanomalina pseudomenardii (470.75 mbsf). Age: 61.0 59.2 Ma, late Palaeocene (Selandian).

P3a. FAD of Morozovella angulata (493.33 mbsf) to FAD of Igorina albeari (484.55 mbsf). Age: 61.0-60.0 Ma, early late Palaeocene (Selandian). The boundaries for this subzone cannot be placed with a high degree of confidence because there is an $8 \mathrm{~m}$ core gap below the FAD of Morozovella angulata, and an $8 \mathrm{~m}$ core gap below the FAD of Igorina albeari ( $\mathrm{Pl} .1$, figs 7-9). Common species in Subzone P3a at Site 762 include Globanomalina compressa, Parasubbotina varianta, P. pseudobulloides and Subbotina triloculinoides. The overall assemblage of Subzone P3a at Site 762 is similar to that described elsewhere (Olsson et al., 1999), and includes the first appearances of the Morozovella angulatalconicotruncata complex, which marks the beginning of the late Palaeocene Morozovella radiation.

P3b. FAD of Igorina albeari (484.55 mbsf) to FAD of Globanomalina pseudomenardii (470.75 mbsf). Age: 60.0 59.2 Ma, late Palaeocene (Selandian). The upper boundary for Subzone P3b is well defined because Acarinina subsphaerica, $A$. nitida and $A$. mckannai have near-simultaneous FADs with Globanomalina pseudomenardii (P1. 1, figs 10-12) at Site 762 and elsewhere (Olsson et al., 1999). Common species in Subzone P3b at Site 762 include Morozovella angulata, M. conicotruncata, Parasubbotina variospira, Subbotina triloculinoides, Globanomalina chapmani, $G$. ehrenbergi and the first appearance of Acarinina with A. strabocella. This assemblage is typical of Subzone P3b faunal assemblages (Olsson et al., 1999), except that Morozovella velascoensis does not make its first appearance here but at the base of Zone P4c.

P4. Total range of Globanomalina pseudomenardii (470.75 to $423.03 \mathrm{mbsf}$ ). Age: $59.2-55.9 \mathrm{Ma}$, middle Late Palaeocene (late Selandian-Thanetian). The lower boundary of Zone P4 is placed with moderate conference because Globanomalina pseudomenardii has a patchy occurrence at Site 762 and has a similar morphology to both $G$. ehrenbergi and G. chapmani ( $\mathrm{Pl}$. 1, figs 10-12). Indeed, preliminary work on the foraminifera at Site 762 (Shipboard Scientific Party, 1990) described Globanomalina pseudomenardii as the inflated 'chapmani type'. However, there is morphological variability within this species with some of the smaller specimens displaying a distinct keel and a 
H. J. L. Hancock et al.

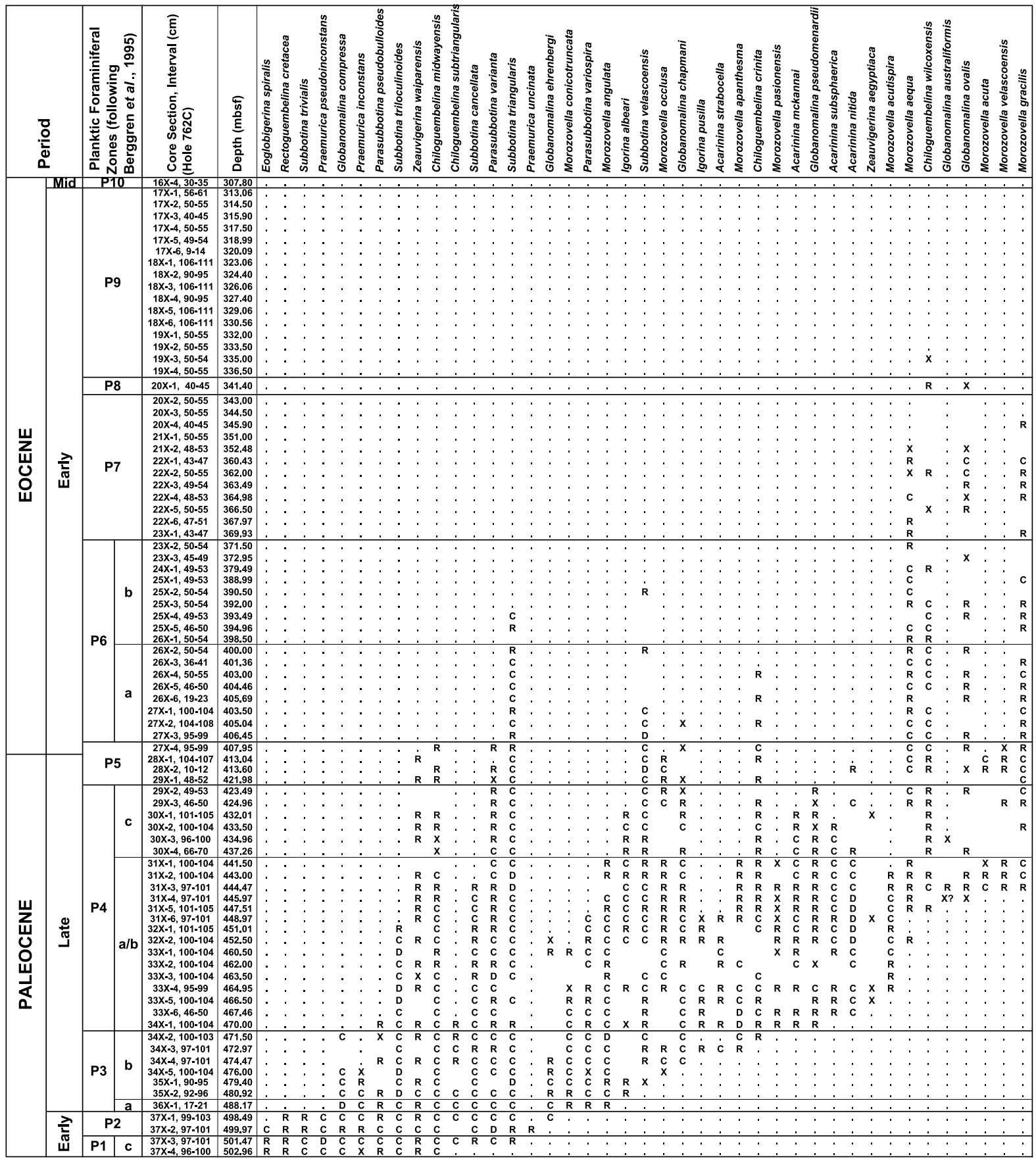

Fig. 3. Distribution of planktic foraminifera at Site 762 .

Notes: $\mathrm{D}=$ dominant, $\mathrm{C}=$ common, $\mathrm{R}=$ rare and $\mathrm{X}=$ extremely rare.

$A=$ Acarinina, $S=$ Subbotina, $M=$ Morozovella, $G=$ Globanomalina, $C=$ Chiloguembelina, $P=$ Parasubbotina .

sharpened angular periphery. It is one of these more typical Globanomalina pseudomenardii morphotypes that marks the $\mathrm{P} 4 / \mathrm{P} 5$ zonal boundary.

P4a-b. FAD of Globanomalina pseudomenardii (470.75 mbsf) to FAD of Acarinina soldadoensis (439.38 mbsf). Age: 59.2 56.5 Ma, middle late Palaeocene (late Selandian-Thanetian). In the global scheme, the LAD of Acarinina subsphaerica
(Pl. 2, figs 14-16) defines the base of Subzone P4b (Olsson et al., 1999). However, at Site 762, this datum occurs in the upper part of Subzone P4c. Consequently, Subzones P4a and P4b cannot be distinguished at Site 762, and they have been combined. Common species of Subzone P4a-b at Site 762 include the Morozovella angulata-conicotruncata complex, M. apanthesma, M. acutispira, Acarinina subsphaerica, A. mckannai, A. nitida, Igorina albeari, Parasubbotina varianta, 
Early Palaeogene planktic foraminifera

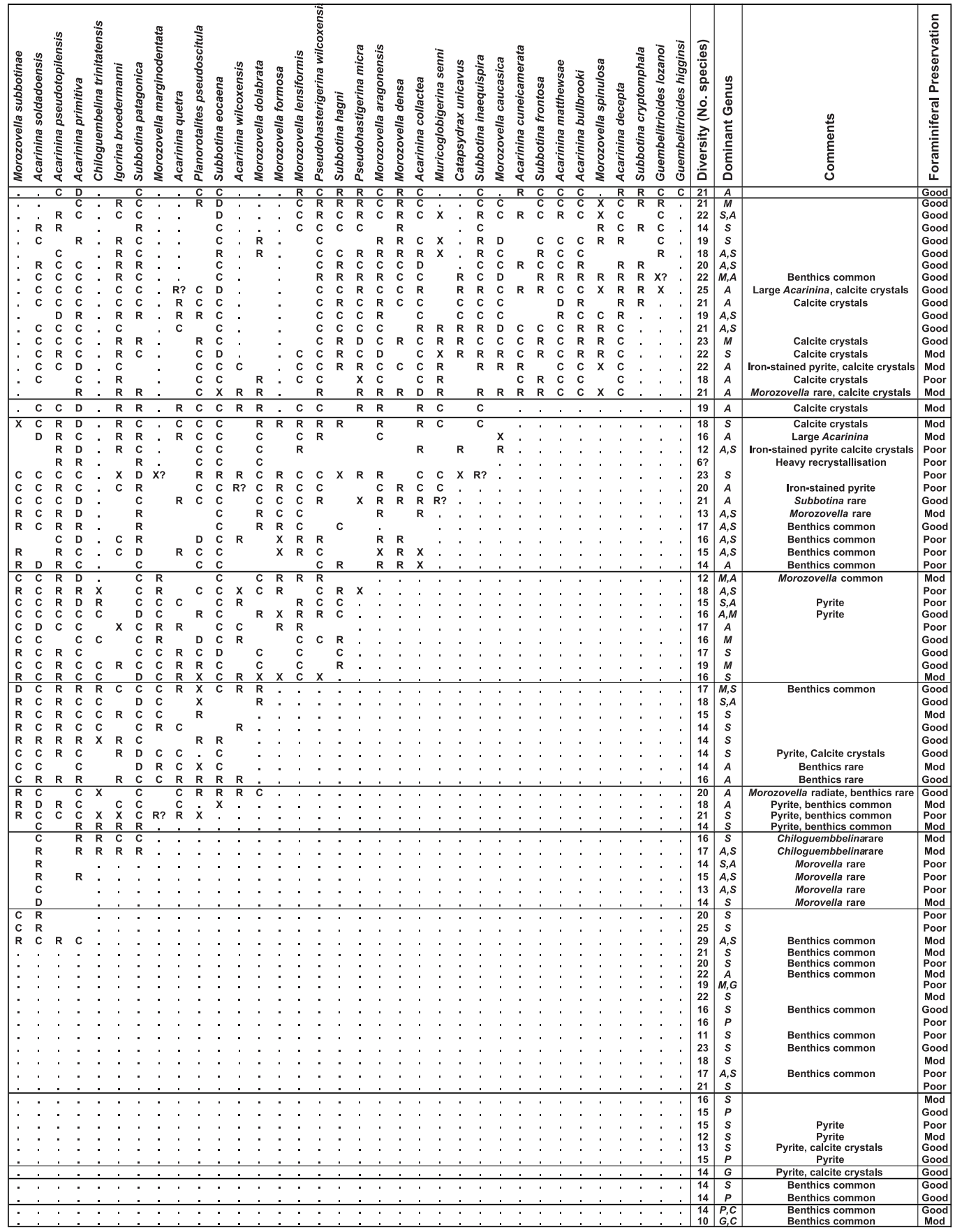

Subbotina triloculinoides, S. triangularis, S. velascoensis and Chiloguembelina midwayensis. Such an assemblage is characteristic of Subzones $\mathrm{P} 4 \mathrm{a}$ and $\mathrm{P} 4 \mathrm{~b}$ in the global scheme (Olsson et al., 1999).

P4c. FAD of Acarinina soldadoensis (439.38 mbsf) to LAD of Globanomalina pseudomenardii (423.03 mbsf). Age: 56.555.9 Ma, late Palaeocene (late Thanetian). At the base of Subzone P4c at Site 762 the FAD of Acarinina soldadoensis (Pl. 1, figs 13-15) coincides with the FADs of $A$. primitiva, $A$. pseudotopilensis, Morozovella velascoensis, $M$. acuta and $M$. aequa as found elsewhere (Olsson et al., 1999). The interval assigned to this zone at Site 762 is relatively large compared to that of the global scheme (Berggren et al., 1995) and its base in particular does not correlate well with the nannofossil zones for the site (Siesser \& Bralower, 1992). However, we regard the lower boundary of Subzone P4c as being well defined at Site 762 because so many species make their first appearances at its base, representing a pattern consistent with that of the global scheme. 


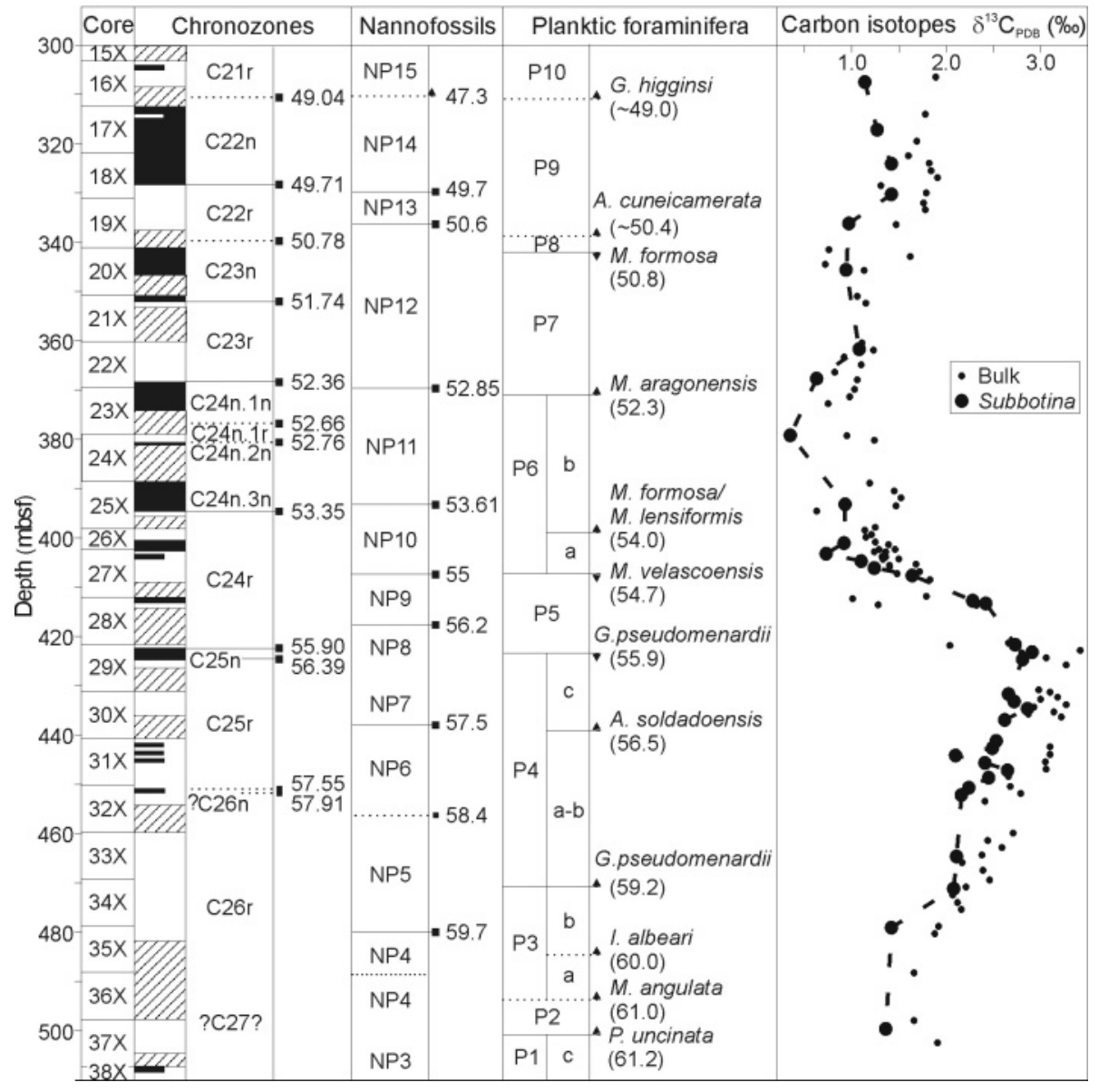

Fig. 4. Comparison of planktic foraminiferal biozones (this study), nannofossil biozones (Siesser \& Bralower, 1992), recalibrated magnetostratigraphy (this study) and carbon isotope data for Subbotina (this study) and the bulk sediment (Thomas et al., 1992) for the early Palaeogene interval at ODP Site 762. Ages follow Berggren et al. (1995). Larger circles with dashed lines are $\delta^{13} \mathrm{C}$, Subbotina specimens; small filled circles are $\delta^{13} \mathrm{C}$, bulk sediment.
P5. LAD of Globanomalina pseudomenardii (423.03 mbsf) to LAD of Morozovella velascoensis (407.23 mbsf). Age: 55.9-54.7 Ma, latest Palaeocene-early Eocene (latest Thanetian-earliest Ypresian). The distribution of Morozovella velascoensis (Pl. 1, figs 16-18) is somewhat patchy at Site 762 (Fig. 3) and may not represent its true range. Such a pattern may relate to the higher latitudes and cooler temperatures for the Exmouth Plateau during the time of deposition (due to its location at that time, well to the south), as the species is typical of more tropical areas (Olsson et al., 1999). Faunal assemblages in Zone P5 at Site 762 commonly include Subbotina velascoensis, S. triangularis, S. patagonica, Igorina broedermanni, Morozovella aequa, M. subbotinae, Acarinina soldadoensis and A. primitiva, all typical of other global locations (Berggren et al., 1995). The FADs of Morozovella dolobrata and Acarinina wilcoxensis occur simultaneously in upper Zone P5, which correlates well with their FADs in New Zealand near the base of the Waipawan (Hornibrook et al., 1989). The LADs of Morozovella acuta and M. occlusa occur in upper Zone P5, consistent with the global scheme (Olsson et al., 1999). However, the distinct morphotypes Morozovella allisonensis, M. africana and Acarinina sibaiyaensis that developed and diversified during a brief interval of P5 (e.g. Kelly et al., 1998; Pardo et al., 1999) were not found at Site 762. As discussed later, these species may not have been recovered because of a $5 \mathrm{~m}$ core gap in uppermost P5 between $762 \mathrm{C}-28 \mathrm{X}-1$ and $-27 \mathrm{X}-4$.
P6. LAD of Morozovella velascoensis (407.23 mbsf) to FAD of Morozovella aragonensis (370.74 mbsf). Age: 54.7-52.3 Ma, early Eocene (early Ypresian).

P6a. LAD of Morozovella velascoensis (407.23 mbsf) to FAD of Morozovella formosa or Morozovella lensiformis (399.25 mbsf). Age: 54.7-54.0 Ma, earliest Eocene (earliest Ypresian). At Site 762 and elsewhere (Berggren et al., 1995) the FADs of Morozovella formosa (P1. 1, figs 19-20; Pl. 2, fig. 1) and $M$. lensiformis (P1. 2, figs 2-4) coincide. Common species found in this zone at Site 762 include Subbotina patagonica, S. triangularis, Acarinina soldadoensis, A. primitiva, Morozovella subbotinae, M. marginodentata, Chiloguembelina wilcoxensis and $C$. crinita. This overall assemblage is typical for Subzone P6a (Blow, 1979, as Subzone Zone P7; Berggren et al., 1995).

There is a problem within the interval containing Subzone P6a at Site 762 with the labelling of core $-26 \mathrm{X}$. According to the drilling log, the depth of this core is 398.0 to $402.5 \mathrm{mbsf}(4.5 \mathrm{~m}$ thick). However, there is $c .8 \mathrm{~m}$ of core photographed and illustrated in the lithological $\log$ for core $-26 \mathrm{X}$. As the next coring interval, $-27 \mathrm{X}$, starts at $402.5 \mathrm{mbsf}$, there is $c .3 .5 \mathrm{~m}$ of core that has not been accounted for.

P6b. FADs of Morozovella formosa or Morozovella lensiformis (399.25 mbsf) to FAD of Morozovella aragonensis (370.74 mbsf) (P1. 2, figs 5-7). Age: 54.0-52.3 Ma, early Eocene (early Ypresian). At Site 762 and elsewhere, the FADs of Morozovella 


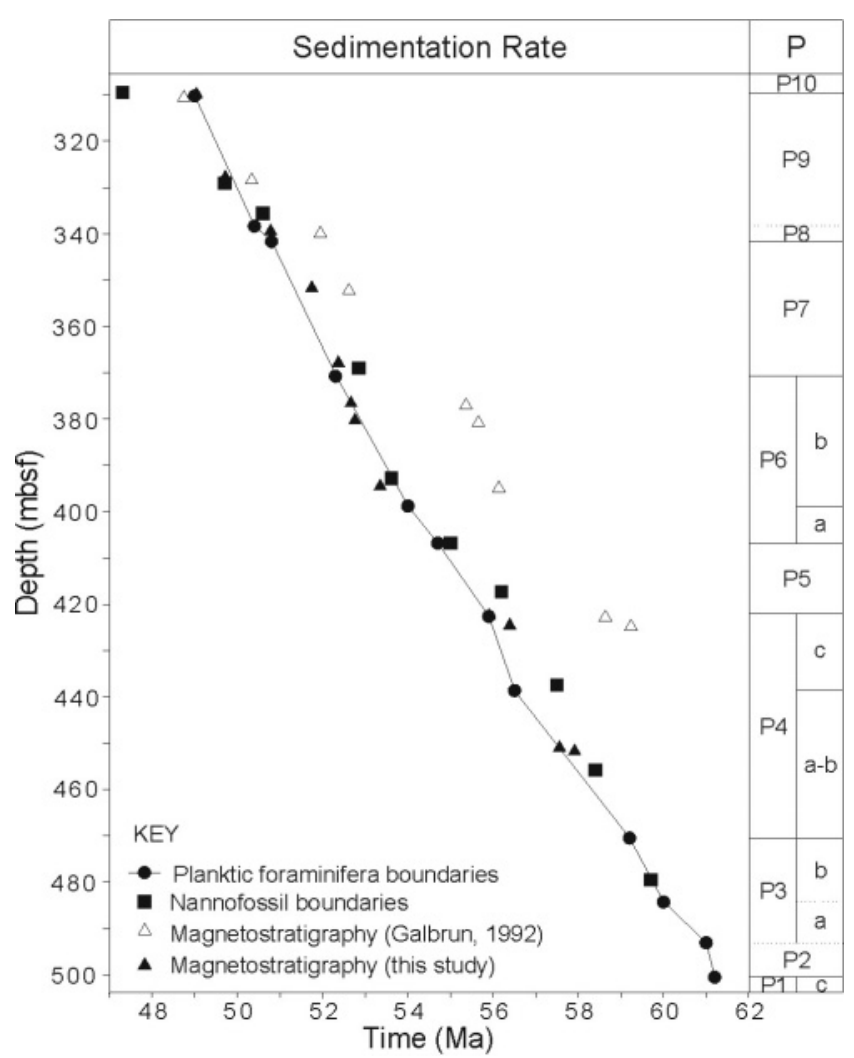

Fig. 5. Sedimentation rates calculated from planktic foraminifera (this study) and nannofossils (Siesser \& Bralower, 1992) compared with published magnetostratigraphy (Galbrun, 1992) and recalibrated magnetostratigraphy (this study). The original magnetostratigraphy deviates from the other curves, showing where the major adjustment was made for Chron $22 \mathrm{n}$ at $49 \mathrm{Ma}$. Sedimentation rates calculated from the planktic foraminiferal and nannofossil biozonation using the global scheme are $1.5 \mathrm{~cm} \mathrm{ka}^{-1}$ and $1.4 \mathrm{~cm} \mathrm{ka}^{-1}$ respectively. $\mathrm{P}$, planktic foraminiferal biozones (this study).

lensiformis and M. formosa coincide, although at Site 762 the latter species is rare. The FAD of Pseudohasterigina wilcoxensis also occurs at the base of Subzone P6b at Site 762. In tropical assemblages this datum occurs at the P5/P6 boundary but has a delayed entry in mid-high latitude regions within the P6b-P7 interval (Blow, 1979, as Subzone Zone P7; Berggren et al., 1995). Faunal assemblages in Subzone P6a at Site 762 dominantly consist of Subbotina eocaena, S. patagonica, Acarinina quetra, Acarinina soldadoensis, A. primitiva, Morozovella lensiformis, M. subbotinae, M. gracilis, M. marginodentata, M. aequa and Planorotalites pseudoscitula. These are typical assemblages found elsewhere (Blow, 1979, as Subzone Subzone P8a; Berggren et al., 1995). However, at other locations, the LAD of M. subbotinae occurs within Subzone P6b (Berggren et al., 1995), but at Site 762, this datum occurs later in Zone P7.

P7. FAD of Morozovella aragonensis (370.74 mbsf) to LAD of Morozovella formosa (342.25 mbsf). Age: 52.3-50.8 Ma, middle early Eocene (mid-Ypresian). The upper boundary of this zone is poorly constrained as the occurrence of Morozovella formosa is patchy. Faunal assemblages in Zone P7 at Site 762 are dominated by Acarinina soldadoensis, A. primitiva, A. quetra, Muricoglobigerina senni, Subbotina eocaena, S. patagonica, S. hagni, Morozovella aequa, M. gracilis, M. dolobrata, $M$. lensiformis and Planorotalites pseudoscitula. These assemblages are typical of Zone P7 assemblages found in other parts of the globe (Blow, 1979, as Subzone 8b; Berggren et al., 1995). The LAD of Morozovella aequa occurs in Zone P7 in the global scheme (Olsson et al., 1999), however, at Site 762, it occurs slightly later in our Zone P8.

P8. LAD of Morozovella formosa (342.25 mbsf) to FAD of secondary marker species Acarinina cuneicamerata (338.95 mbsf). Age: 50.8-50.4 Ma, late Early Eocene (late Ypresian). The top of Zone P8 is defined by the FAD of Planorotalites palmerae in the global scheme (Berggren et al., 1995). This primary marker species is absent at Site 762. Other authors have noted that Planorotalites palmerae has a very patchy geographical distribution (Toumarkine \& Luterbacher, 1985). In the absence of Planorotalites palmerae, the top of this zone is defined by the FAD of Acarinina cuneicamerata (Pl. 2, figs 8-10) and the common appearance of A. bullbrooki (W. A. Berggren, pers. comm., 1999). Common species found in this zone at Site 762 and elsewhere (Toumarkine \& Luterbacher, 1985) include Acarinina primitiva, A. pseudotopilensis, A. soldadoensis, A. collactea, A. decepta, Muricoglobigerina senni, Morozovella aragonensis, Subbotina inaequispira, S. eocaena and Pseudohastigerina wilcoxensis.

P9. FAD of secondary marker species Acarinina cuneicamerata (338.95 mbsf) to FAD of secondary marker species Guembelitrioides higginsi (310.91 mbsf). Age: 50.4 49.0 Ma, late early Eocene (latest Ypresian). The FAD of Hantkenina nuttalli defines the top of Zone P9 in the global scheme (Toumarkine, 1981; Berggren et al., 1995). However, this datum occurs higher in the sedimentary column at Site 762 (section $762 \mathrm{C}-15 \mathrm{X}-2$ ) co-existing with taxa characteristic of Zone P11. The placement of this boundary has been problematic elsewhere because of the late arrival and/or rare early appearance of Hantkenina nuttalli (e.g. McGowran, 1974). The LAD of Planorotalites palmerae is another criterion for the P9/P10 boundary (W. A. Berggren, pers. comm., 1999). Unfortunately, this species was not found at Site 762. The FAD of Guembelitrioides higginsi (Pl. 2, figs 11-13) is close to the P9/P10 boundary at other locations (W. A. Berggren, pers. comm., 1999). We therefore use this datum to mark the top of Zone P9. Common species in Zone P9 at Site 762 and elsewhere (Toumarkine \& Luterbacher, 1985; Berggren et al., 1995) include Acarinina primitiva, A. soldadoensis, A. pseudotopilensis, A. collactea, A. cuneicamerata, A. matthewsae, A. bullbrooki, A. decepta, Morozovella lensiformis, M. densa, M. aragonensis, M. caucasica, Subbotina patagonica, S. eocaena, S. inaequispira, S. frontosa, S. hagni, Pseudohasterigina wilcoxensis, Ph. micra, Planorotalites pseudoscitula, Igorina broedermanni and Guembelitrioides lozanoi (in upper P9).

P10. FAD of secondary marker species Guembelitrioides higginsi (310.91 mbsf) to FAD of Globigerapsis kugleri. Age: 49.0 45.8 Ma, early middle Eocene (early Lutetian). Only one sample within Zone P10 was examined. The top of this zone, therefore, lies above our sampling interval. The sample examined contains Guembelitrioides higginsi and Truncorotaloidesspp., which are characteristic species of Zone P10 (Berggren et al., 1995). 


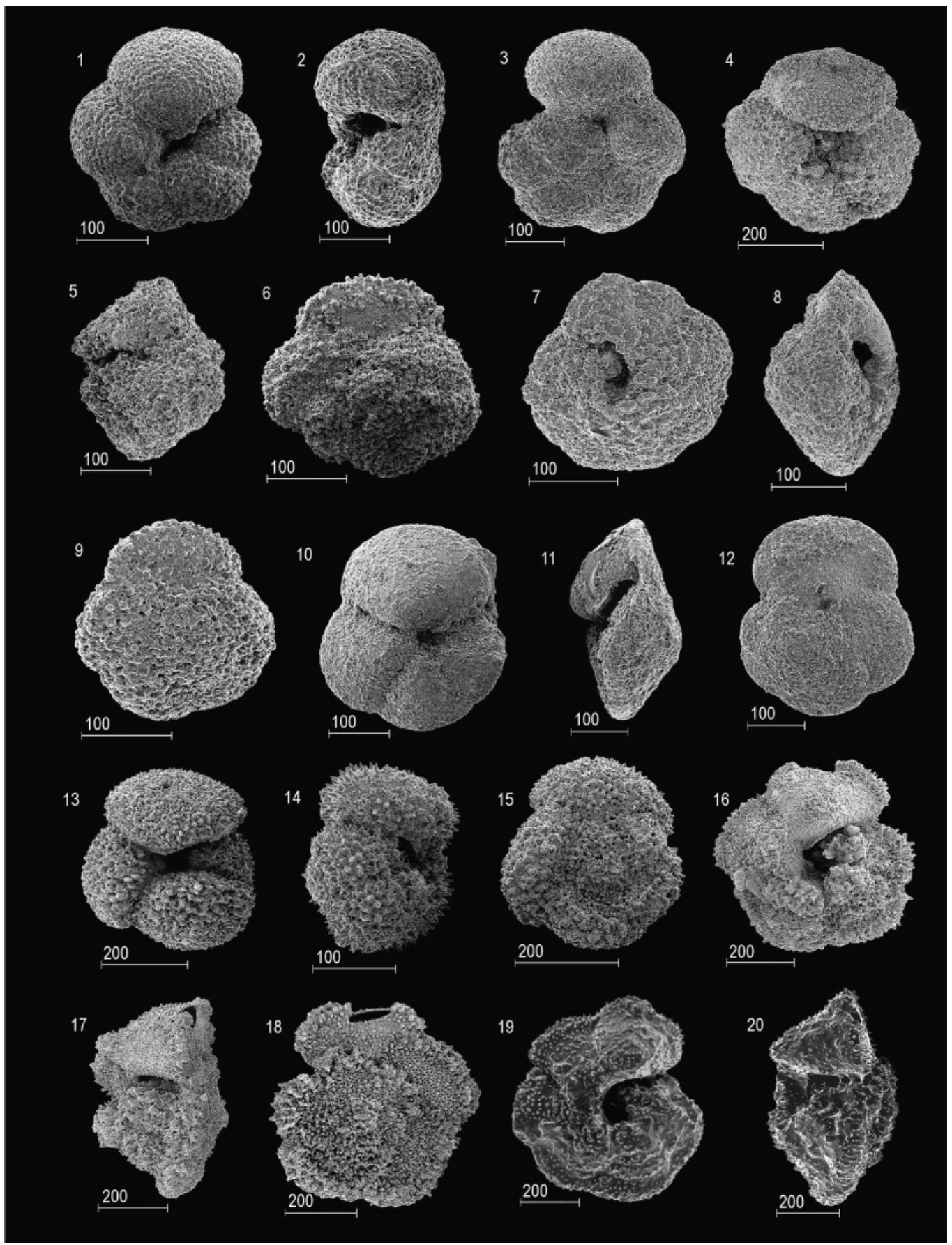

Explanation of Plate 1

Scale bars in $\mu \mathrm{m}$ for all figured specimens. Figs 1-3. Praemurica uncinata (Bolli, 1957a,b): 1, umbilical view, CPC 35739, sample 762-37X-2, 97-100 cm; 2, side view, CPC 25740, sample 762C-37X-2, 97-100 cm; 3, dorsal view, CPC 35741, sample 762C-37X-2, 97-100 cm. Figs 4-6. Morozovella angulata (White, 1928a,b): 4, umbilical view, CPC 35742, sample 762C-33X-1, 100-104 cm; 5, side view, CPC 35743, sample 762C-33X-2, 100-104 cm; 6, dorsal view, CPC 35744, sample 762C-34X-3, 95-99 cm. Figs 7-9. Igorina albeari (Cushman \& Bermúdez, 1949): 7, umbilical view, CPC 35745, sample 762C-31X-3, 97-101 cm; 8, side view, CPC 35746, sample 762C-33X-4, 95-99 cm; 9, dorsal view, CPC 35747, sample 762C-31X-2, 100-104 cm. Figs 10-12. Globanomalina pseudomenardii (Bolli, 1957a): 10, umbilical view, CPC 35748, sample 762C-31X-2, 100-104 cm; 11, side view, CPC 35749, sample 762C-31X-3, 97-101 cm; 12, dorsal view, CPC 35750, sample 762C-29X-3, 46-50 cm. Figs 13-15. Acarinina soldadoensis (Brönnimann, 1952): 13, umbilical view, CPC 35751, sample 762C-17X-4, 50-55 cm; 14, side view, CPC 35752, sample $762 \mathrm{C}-18 \mathrm{X}-2,90-95 \mathrm{~cm} ; \mathbf{1 5}$, dorsal view, CPC 35753 , sample $762 \mathrm{C}-17 \mathrm{X}-4,50-55 \mathrm{~cm}$. Figs 16-18. Morozovella velascoensis (Cushman, 1925): 16, umbilical view, CPC 35754, sample 762C-31X-3, 97-101 cm; 17, side view, CPC 35754, sample 762C-31X-3, 97-101 cm; 18, dorsal view, CPC 35754, sample 762C-31X-3, 97-101 cm. Figs 19-20. Morozovella formosa (Bolli, 1957a): 19, umbilical view, CPC 35755, sample 762C-22X-3, 49-54 cm; 20, side view, CPC 35755, sample 762C-22X-3, 49-54 cm. 
Early Palaeogene planktic foraminifera

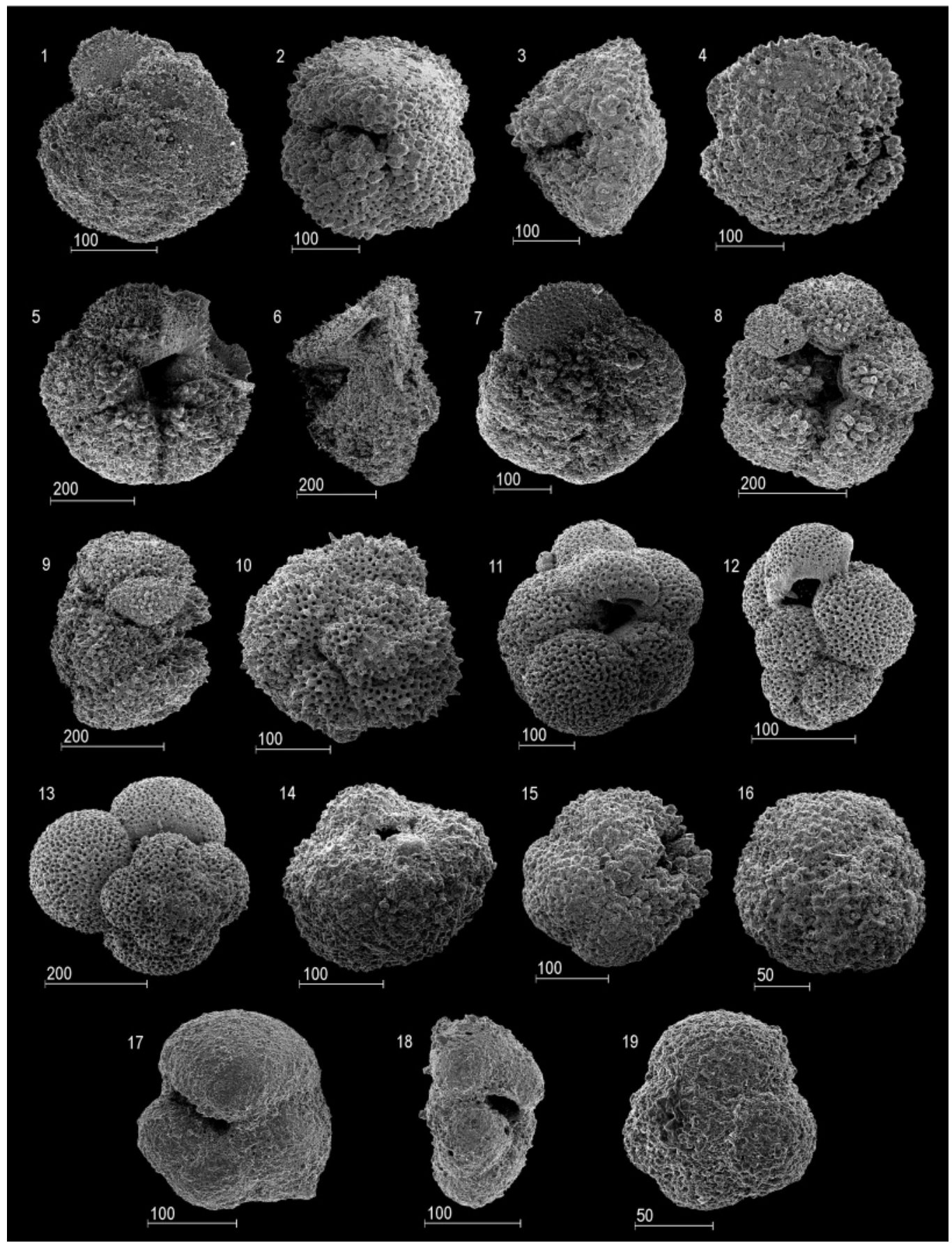

Explanation of Plate 2

Scale bars in $\mu \mathrm{m}$ for all figured specimens. Fig. 1. Morozovella formosa (Bolli 1957a). Dorsal view, CPC 35756, sample 762C-22X-3, 49-54 cm. Figs 2-4. Morozovella lensiformis (Subbotina, 1953): 2, umbilical view, CPC 35757, sample 762C-23X-2, 50-54 cm; 3, side view, CPC 35758, sample 762C-23X-2, 50-54 cm; 4, dorsal view, CPC 35759, sample 762C-23X-2, 50-54 cm. Figs 5-7. Morozovella aragonensis (Nuttall, 1930): 5, umbilical view, CPC 35760, sample 762C-17X-2, 50-55 cm; 6, side view, CPC 35761, sample 762C-17X-5, 49-54 cm; 7, dorsal view, CPC 35762, sample 762C-17X-5, 49-54 cm. Figs 8-10. Acarinina cuneicamerata (Blow, 1979): 8, umbilical view, CPC 35763, sample 762C-19X-4, 50-55 cm; 9, side view, CPC 35763, sample 762C-19X-4, 50-55 cm; 10, dorsal view, CPC 35764, sample 762C-19X-3, 50-54 cm. Figs 11-13. Guembelitrioides higginsi (Bolli, 1957b): 11, umbilical view, CPC 35765, sample 762C-16X-4, 30-35 cm; 12, side view, CPC 35766, sample 762C-16X-4, 30-35 cm; 13, dorsal view, CPC 35767, sample 762C-16X-4, 30-35 cm. Figs 14-16. Acarinina subsphaerica (Subbotina, 1947): 14, umbilical view, CPC 35768, sample 762C-31X-3, 97-101 cm; 15, side view, CPC 35769, 762C-31X-6, 97-101 cm; 16, dorsal view, CPC 35770, sample 762C-32X-2, 100-104 cm. Figs 17-19. Globanomalina australiformis (Jenkins, 1965): 17, umbilical view, CPC 35771, sample 762C-31X-3, 97-101 cm; 18, side view, CPC 35772, sample 762C-31X-3, 97-101 cm; 19, dorsal view, CPC 35773, sample 762C-30X-3, 96-100 cm. 


\begin{tabular}{|c|c|c|c|}
\hline $\begin{array}{l}\text { Core section, interval } \\
(\mathrm{cm})\end{array}$ & $\begin{array}{l}\text { Depth } \\
\text { (mbsf) }\end{array}$ & $\begin{array}{l}\text { Subbotina spp. } \\
\text { Analysed }\end{array}$ & $\begin{array}{r}\delta^{13} \mathrm{C} \\
(\% 0)\end{array}$ \\
\hline $15 X-3,80-85$ & 297.30 & S. patagonica & 1.34 \\
\hline $16 X-4,30-35$ & 307.80 & S. patagonica & 1.15 \\
\hline $17 X-4,50-55$ & 317.50 & S. patagonica & 1.28 \\
\hline $18 \mathrm{X}-2,90-95$ & 324.40 & S. patagonica & 1.43 \\
\hline $18 X-6,106-111$ & 330.56 & S. patagonica & 1.43 \\
\hline $19 X-4,50-55$ & 336.50 & S. patagonica & 0.98 \\
\hline $20 X-4,40-45$ & 345.90 & S. patagonica & 0.9 \\
\hline $22 X-2,50-55$ & 362.00 & S. patagonica & 1.09 \\
\hline $22 X-6,47-51$ & 367.97 & S. patagonica & 0.64 \\
\hline $24 X-1,49-53$ & 379.49 & S. patagonica & 0.36 \\
\hline $25 X-4,49-53$ & 393.49 & S. patagonica & 0.94 \\
\hline $26 \mathrm{X}-3,36-41$ & 401.36 & S. patagonica & 0.93 \\
\hline $27 \mathrm{X}-1,100-104$ & 403.50 & S. patagonica & 0.74 \\
\hline $27 X-2,104-108$ & 405.04 & S. patagonica & 1.11 \\
\hline 27X-3, 95-99 & 406.45 & S. triangularis & 1.25 \\
\hline $27 X-4,95-99$ & 407.95 & S. triangularis & 1.65 \\
\hline $28 X-1,104-107$ & 413.04 & S. triangularis & 2.29 \\
\hline $28 \mathrm{X}-2,10-12$ & 413.60 & S. triangularis & 2.43 \\
\hline $29 X-1,48-52$ & 421.98 & S. triangularis & 2.74 \\
\hline $29 \mathrm{X}-2,49-53$ & 423.49 & S. triangularis & 2.92 \\
\hline $29 X-3,46-50$ & 424.96 & S. triangularis & 2.82 \\
\hline $30 \mathrm{X}-1,101-105$ & 432.01 & S. triangularis & 2.67 \\
\hline $30 X-2,100-104$ & 433.50 & S. triangularis & 2.73 \\
\hline $30 X-3,96-100$ & 434.96 & S. triangularis & 2.87 \\
\hline $30 X-4,66-70$ & 437.26 & S. triangularis & 2.63 \\
\hline $31 X-1,100-104$ & 441.50 & S. triangularis & 2.54 \\
\hline $31 X-2,100-104$ & 443.00 & S. triangularis & 2.50 \\
\hline $31 X-3,97-101$ & 444.47 & S. triangularis & 2.11 \\
\hline $31 X-4,97-101$ & 445.97 & S. triangularis & 2.42 \\
\hline $31 X-5,101-105$ & 447.51 & S. triangularis & 2.66 \\
\hline $31 X-6,97-101$ & 448.97 & S. triangularis & 2.46 \\
\hline $32 X-1,101-105$ & 451.01 & S. triangularis & 2.25 \\
\hline $32 X-2,100-104$ & 452.50 & S. triloculinoides & 2.17 \\
\hline $33 \mathrm{X}-4,95-99$ & 464.95 & S. triloculinoides & 2.12 \\
\hline $34 X-2,100-103$ & 471.50 & S. triloculinoides & 2.09 \\
\hline $35 \mathrm{X}-1,90-95$ & 479.40 & S. triloculinoides & 1.43 \\
\hline $37 \mathrm{X}-2,97-101$ & 499.97 & S. triloculinoides & 1.37 \\
\hline
\end{tabular}

Table 1. Carbon isotope composition of Subbotina spp.

\section{Carbon isotopes}

The $\delta^{13} \mathrm{C}$ of Subbotina tests averages $1.84 \%$ across our sampled interval but varies significantly between 0.36 and $2.92 \%$ (Table 1; Fig. 4). From the lowest sampled interval in P1 (502.96 mbsf) to the base of Zone P5 (423.49 mbsf) $\delta^{13} \mathrm{C}$ gradually increases by about 2.0\%. There is a marked decrease in $\delta^{13} \mathrm{C}$ through Zone P5 (423.49 to $407.95 \mathrm{mbsf}$ ) by about 2.5\% . From the top of Zone P5 (407.95 mbsf) to the top of the sampled interval in Zone P10 (307.80 mbsf) $\delta^{13} \mathrm{C}$ is relatively constant, except for a slight drop in upper Zone P6. The Subbotina $\delta^{13} \mathrm{C}$ curve mirrors the bulk carbonate $\delta^{13} \mathrm{C}$ curve at Site 762 (Thomas et al., 1992), although Subbotina $\delta^{13} \mathrm{C}$ values are typically $0.5 \%$ lower at similar depth. This offset in $\delta^{13} \mathrm{C}$ is expected because surface waters are generally enriched in ${ }^{13} \mathrm{C}$ relative to deeper waters of the thermocline.

The exogenic carbon cycle includes all carbon stored in the ocean, atmosphere and biomass reservoirs. Secular changes can occur in this exogenic carbon cycle with variations in carbon inputs or outputs to the ocean or atmosphere (e.g. Kump \& Arthur, 1999; Dickens, 2001). Because carbon cycles through all reservoirs of the exogenic carbon cycle over relatively short time intervals, about 2000 years at present day, major perturbations in the isotopic composition of the exogenic carbon cycle will be observed in all carbon reservoirs at nearly the same time (e.g. Dickens et al., 1997). The early Palaeogene is especially amenable for correlating widespread locations by this "carbon isotope stratigraphy" because there are a series of prominent $\delta^{13} \mathrm{C}$ excursions in the exogenic carbon cycle of long and short duration (e.g. Zachos et al., 1993; Corfield, 1994; Dickens et al., 1997, Zachos et al., 2001). Most key features of the global carbon isotope record for the Palaeogene (Fig. 1) can be recognized at Site 762 (Fig. 4). Importantly, when the $\delta^{13} \mathrm{C}$ variations at Site 762 are placed within the timescale defined by our foraminiferal biozones, they match within $0.5 \mathrm{Ma}$ the age pattern suggested for the global $\delta^{13} \mathrm{C}$ record by Berggren et al. (1995). This cross-correlation supports the planktic foraminiferal zonation we have developed for Site 762 .

\section{Integrated biostratigraphy}

In the previously published nannofossil biostratigraphy for Site 762 (Siesser \& Bralower, 1992), nannofossil datums and biozones were calibrated to the timescale of Haq et al. (1987). We have recalibrated the nannofossil biozones with the most current global timescale (Berggren et al., 1995). The revised nannofossil biostratigraphy at Site 762 agrees reasonably well with both the planktic foraminiferal and carbon isotope stratigraphy. However, there are discrepancies, notably the placement of the NP6/NP7, NP8/NP9, boundaries, which appear to be too high in the column (Fig. 4). There are several possible reasons for such anomalies. First, key nannofossil markers are very rare at Site 762 (Shipboard Scientific Party, 1990) and may have been missed. Second, the high latitude of the Exmouth Plateau in the early Palaeogene may have put some species at the limits of their biogeographic range (Wonders, 1992) resulting in certain nannofossil and foraminiferal biomarkers at Site 762 being responsive to distribution patterns which applied to the north Australian margin rather than the temporal controls of evolution and extinction. Third, the mismatches could, at least in part, be artefacts of sampling resolution.

\section{Magnetostratigraphy problem}

Galbrun (1992) determined the pattern of polarity reversals for Upper Cretaceous and Lower Tertiary core obtained from Site 762. As noted by Berggren et al. (1995, p. 184), the magnetostratigraphy raises a correlation problem. Starting with Chron $\mathrm{C} 22 \mathrm{n}$ and continuing back through the Palaeocene, there are significant discrepancies between magnetostratigraphic and nannofossil datums at Site 762 (cf. Siesser \& Bralower, 1992; Galbrun, 1992). In particular, Chron C22n has been placed within Zone NP12. However, according to global stratigraphic schemes, Chron C22n occurs within NP14 (Berggren et al., 1995). Three plausible explanations could account for the miscorrelation. First, the nannofossil zones at Site 762 could be diachronous by some 1.5 Ma with the global timescale. Second, recognition of key nannofossil zones could be incorrect. Third, the polarity chrons could have been mislabelled or misinterpreted. It is noteworthy that the P7/P8 zonal boundary roughly coincides with the top of Chron C23n in global schemes (Berggren et al., 1995), but at Site 762 it coincides with the chron labelled C22n (Galbrun, 1992). It is therefore likely that Chron C23n was mistaken for Chron C22n in previous work. Making 
Early Palaeogene planktic foraminifera

\begin{tabular}{|c|c|c|c|c|}
\hline \multirow{2}{*}{ Datum } & \multicolumn{3}{|c|}{$\begin{array}{c}\text { Sample } \\
\text { Core section, interval }(\mathrm{cm})\end{array}$} & \multirow{2}{*}{$\begin{array}{l}\text { Depth } \\
\text { (mbsf) }\end{array}$} \\
\hline & $(\mathrm{Ma})^{\mathrm{a}}$ & upper & lower & \\
\hline FAD $N$. fulgens, NP14/NP15 & 47.3 & $16 \mathrm{X}-3,99$ & $16 \mathrm{X}, \mathrm{CC}$ & 306.99-313.49 \\
\hline FAD G. higginsi, $\mathrm{P} 9 / \mathrm{P} 10$ & 49.0 & $16 \mathrm{X}-4,30$ & $17 X-1,56$ & $307.80-314.01$ \\
\hline $\mathrm{C} 22 \mathrm{n} / \mathrm{C} 22 \mathrm{r}$ & 49.037 & $16 X-4,16$ & $17 X-1,26$ & $307.67-312.76$ \\
\hline FAD D. sublodoensis, NP13/NP14 & 49.7 & $18 X-5,100$ & $18 \mathrm{X}-6,100$ & $329.00-330.51$ \\
\hline $\mathrm{C} 22 \mathrm{r} / \mathrm{C} 22 \mathrm{n}$ & 49.714 & $18 \mathrm{X}-4,110$ & $18 \mathrm{X}-5,51$ & $327.60-328.51$ \\
\hline FAD A. cuneicamerata, $\mathrm{P} 8 / \mathrm{P} 9$ & 50.4 & $19 X-4,50$ & $20 \mathrm{X}-1,40$ & $336.50-341.40$ \\
\hline LAD $T$. orthostylus, NP12/NP13 & 50.6 & $19 \mathrm{X}-2,101$ & $19 \mathrm{X}-3,101$ & $335.51-337.01$ \\
\hline $\mathrm{C} 23 \mathrm{n} / \mathrm{C} 22 \mathrm{r}$ & 50.778 & $19 \mathrm{X}-5,30$ & $20 \mathrm{X}-1,53$ & $337.80-341.52$ \\
\hline LAD $M$. formosa, $\mathrm{P} 7 / \mathrm{P} 8$ & 50.8 & $20 X-1,45$ & $20 X-2,55$ & $341.45-343.05$ \\
\hline $\mathrm{C} 23 \mathrm{r} / \mathrm{C} 23 \mathrm{n}$ & 51.743 & $21 \mathrm{X}-1,107$ & $21 X-2,23$ & $351.57-352.23$ \\
\hline FAD $M$. aragonensis, $\mathrm{P} 6 \mathrm{~b} / \mathrm{P} 7$ & 52.3 & $22 X-3,49$ & $22 \mathrm{X}-4,48$ & $369.93-371.55$ \\
\hline $\mathrm{C} 24 \mathrm{n} \cdot 1 \mathrm{n} / \mathrm{C} 23 \mathrm{r}$ & 52.364 & $22 X-6,27$ & $22 X-6,81$ & $367.77-368.32$ \\
\hline C24n.1r/C24n.1n & 52.663 & $23 \mathrm{X}, \mathrm{CC}, 33$ & $24 X-1,61$ & $373.83-379.61$ \\
\hline FAD D. lodoensis, NP11/NP12 & 52.85 & $22 \mathrm{X}-6,100$ & $23 \mathrm{X}-1,100$ & $368.50-370.50$ \\
\hline $\mathrm{C} 24 n .2 \mathrm{n} / \mathrm{C} 24 \mathrm{n} .1 \mathrm{r}$ & 52.757 & $24 \mathrm{X}-1,124$ & $24 \mathrm{X}, \mathrm{CC}, 25$ & $380.24-380.65$ \\
\hline $\mathrm{C} 24 \mathrm{r} / \mathrm{C} 24 \mathrm{n} .3 \mathrm{n}$ & 53.347 & $25 X-4,139$ & $25 X-5,27$ & $394.40-394.76$ \\
\hline LAD $T$. contortus, NP10/NP11 & 53.61 & $25 X-3,101$ & $25 X-4,101$ & $392.51-394.01$ \\
\hline FAD M. formosal M. lensiformis, $\mathrm{P} 6 \mathrm{a} / \mathrm{P} 6 \mathrm{~b}$ & 54.0 & $26 \mathrm{X}-1,50$ & $26 \mathrm{X}-2,50$ & $398.50-400.00$ \\
\hline LAD M. velascoensis, $\mathrm{P} 5 / \mathrm{P} 6 \mathrm{a}$ & 54.7 & $27 X-3,99$ & $27 X-4,99$ & 406.46-407.99 \\
\hline FAD $T$. bramlettei, NP9/NP10 & 55.0 & $27 X-3,99$ & $27 \mathrm{X}-4,100$ & $406.49-408.00$ \\
\hline FAD D. multiradiatus, NP7-8/NP9 & 56.2 & $28 \mathrm{X}-1,100$ & $29 \mathrm{X}-1,100$ & $413.00-422.50$ \\
\hline LAD G. pseudomenardii, P4c/P5 & 55.9 & $29 \mathrm{X}-1,52$ & $29 \mathrm{X}-2,53$ & $422.02-424.03$ \\
\hline $\mathrm{C} 25 \mathrm{n} / \mathrm{C} 24 \mathrm{r}$ & 55.904 & $29 \mathrm{X}-1,48$ & $29 \mathrm{X}-1,145$ & $421.98-422.95$ \\
\hline $\mathrm{C} 25 \mathrm{r} / \mathrm{C} 25 \mathrm{n}$ & 56.391 & $29 \mathrm{X}-2,108$ & $29 \mathrm{X}-3,30$ & $424.09-424.81$ \\
\hline FAD A. soldadoensis, $\mathrm{P} 4 \mathrm{a}-\mathrm{b} / \mathrm{P} 4 \mathrm{c}$ & 56.5 & $31 X-3,97$ & $31 X-4,97$ & $437.26-441.50$ \\
\hline FAD D. mohleri, NP6/NP7-8 & 57.5 & $30 \mathrm{X}-3,139$ & $31 \mathrm{X}-1,100$ & $434.00-441.50$ \\
\hline $\mathrm{C} 26 \mathrm{n} / \mathrm{C} 25 \mathrm{r}$ & 57.554 & $32 X-1,52$ & $32 X-1,140$ & $450.52-451.40$ \\
\hline $\mathrm{C} 26 \mathrm{r} / \mathrm{C} 26 \mathrm{n}$ & 57.911 & $32 \mathrm{X}-1,139$ & $32 X-2,50$ & $451.39-452.00$ \\
\hline FAD H. kleinpellii, NP5/NP6 & 58.4 & $32 X-2,103$ & $33 \mathrm{X}-1,109$ & $452.80-459.50$ \\
\hline FAD G. pseudomenardii, $\mathrm{P} 3 \mathrm{~b} / \mathrm{P} 4 \mathrm{a}-\mathrm{b}$ & 59.2 & $34 \mathrm{X}-1,100$ & $34 \mathrm{X}-2,100$ & $470.00-471.50$ \\
\hline FAD F. tympaniformis, NP4/NP5 & 59.7 & $35 X-1,99$ & $35 \mathrm{X}-2,12$ & $479.40-480.12$ \\
\hline $\mathrm{FAD} I$. albeari, $\mathrm{P} 3 \mathrm{a} / \mathrm{P} 3 \mathrm{~b}$ & 60.0 & $35 X-2,92$ & $36 \mathrm{X}-1,17$ & $480.92-488.17$ \\
\hline FAD $M$. angulata, $\mathrm{P} 2 / \mathrm{P} 3 \mathrm{a}$ & 61.0 & $36 \mathrm{X}-1,17$ & $37 \mathrm{X}-1,99$ & 488.17-498.49 \\
\hline FAD $P$. uncinata, $\mathrm{P} 1 \mathrm{c} / \mathrm{P} 2$ & 61.2 & $37 \mathrm{X}-2,97$ & $37 \mathrm{X}-3,97$ & $499.97-501.47$ \\
\hline
\end{tabular}

a Ages from Berggren et al. (1995).

Table 2. Planktic foraminifera, nannofossil and chron (this study) boundary ages at Site 762 .

this correction, and relabelling the chron succession as a consequence, results in a magnetostratigraphy which correlates well with both the planktic foraminiferal zonation and the isotope stratigraphy (Figs 4, 5).

\section{Palaeocene/Eocene transition}

The transition between the Palaeocene and Eocene epochs is characterized by a brief warming event $c$. $55.5 \mathrm{Ma}$. Globally, this event is recognized in marine sediment sequences by a pronounced benthic foraminiferal extinction event, the appearance of distinct planktic foraminiferal morphotypes, and a remarkable -2.5 to $-3 \%$ excursion in $\delta^{13} \mathrm{C}$ (e.g. Kennett \& Stott, 1991; Bains et al., 1999). The distinct morphotypes and abrupt $\delta^{13} \mathrm{C}$ anomaly were not observed at Site 762. The simplest explanation is that the warming event lies in a $5 \mathrm{~m}$ core gap in uppermost Zone P5 between 762C-28X-1 and -27X-4. One check on this interpretation is the occurrence of Gavelinella beccariiformis. This species dominates benthic foraminiferal assemblages during the Palaeocene but disappears at the warming event. At Site 762 it last occurs in section -28X-1, immediately below the core gap. $\mathrm{A}-1.3 \%{ }^{13} \mathrm{C}$ excursion is represented in bulk carbonate from section $-28 \mathrm{X}-2$ to $-28 \mathrm{X}-1$ (Thomas et al., 1992). The start of the warming event may thus be registered in section $-28 \mathrm{X}-1$.

\section{Sedimentation rates}

Collectively, all biostratigraphic and revised magnetostratigraphic datums show a near-linear age-depth relationship. Subzone P4c has a greater rate of sedimentation, which may relate to local processes such as uplift. However, the overall coherency permits the accurate calculation of sedimentation rates for the early Palaeogene sequence at Site 762. Sedimentation rates are remarkably constant at about $1.5 \mathrm{~cm} \mathrm{ka}^{-1}$, which is typical for carbonate oozes on continental margins (Kennett, 1982) but relatively high compared to known Palaeogene sequences that have not been deeply buried. Continuous sedimentation rates also indicate that significant hiatuses are unlikely to exist at Site 762 .

\section{CONCLUSIONS}

Site 762 on the Exmouth Plateau contains an expanded Palaeogene sequence with abundant and well-preserved calcareous 
microfossils, including planktic foraminifera. We have constructed the first detailed early Palaeogene planktic foraminiferal biostratigraphy at this site, and for the region in general (Fig. 3, Table 2). Sediment deposited between 307.8 and 502.96 mbsf spans Zones P1c to P10 (Berggren et al., 1995), although Subzone P4b cannot be recognized. Despite a relatively high latitude Palaeogene location for Site 762, planktic foraminiferal biozones are generally in phase and contain representative assemblages with those of the currently used global scheme for sub-tropical locations. However, rare, patchy or non-occurrences of the zonal marker species such as Globanomalina pseudomenardii, Morozovella velascoensis, Morozovella formosa, Planorotalites palmerae and Hantkenina nuttalli, make some correlations difficult.

The $\delta^{13} \mathrm{C}$ record constructed from tests of Subbotina spp. is similar to that constructed from bulk sediment. Both records show broad-scale excursions which match the global $\delta^{13} \mathrm{C}$ curve. However, the large and short-lived negative $\delta^{13} \mathrm{C}$ excursion that marks the Palaeocene/Eocene transition is at best partially represented at Site 762 , probably because of a core gap. Nannofossil biozonation and magnetic polarity chron records (after adjustment) are consistent with the planktic foraminifera biozonation and the $\delta^{13} \mathrm{C}$ curve (Table 2). Despite core gaps, the integrated stratigraphy at Site 762 suggests that a complete and expanded Early Palaeogene sediment record exists on the Exmouth Plateau. The relatively shallow subsurface depth of this Palaeogene sequence makes the Exmouth Plateau an ideal location for future scientific drilling to understand Palaeogene oceanography.

\section{ACKNOWLEDGEMENTS}

We sincerely thank Christian Thun, Tony Watson, Andrew Kelman and Richard Brown at AGSO for sample preparation, and James Zachos at UC Santa Cruz for isotope analyses. Personal communications with William Berggren, Richard Norris and Brian Huber have helped us tremendously. This research was funded by AGSO for G. Chaproniere and an ARC small grant to G. Dickens; AGSO provided supplementary funding to H. Hancock. All figured specimens are registered and housed in the Commonwealth Palaeontological Collection (CPC), Australian Geological Survey Organisation, Canberra. The remaining assemblages and samples are stored in the general collections of that organization.

\section{Manuscript received 21 August 2000 Manuscript accepted 29 August 2001}

\section{TAXONOMIC LIST}

The early Palaeogene species represented at Site 762 are listed below alphabetically by genus. Planktic foraminiferal specific and generic concepts used here follow those of Olsson et al. (1999) for the Palaeocene, and generally follow those of Toumarkine \& Luterbacher (1985) and Blow (1979) for the early Eocene.

\footnotetext{
Acarinina bullbrooki (Bolli, 1957b)

Acarinina collactea (Finlay, 1939)

Acarinina cuneicamerata (Blow, 1979)
}

Acarinina decepta (Martin, 1943)

Acarinina matthewsae (Blow, 1979)

Acarinina mckannai (White, 1928)

Acarinina nitida (Martin, 1943)

Acarinina primitiva (Finlay, 1947)

Acarinina pseudotopilensis Subbotina, 1953

Acarinina quetra (Bolli, 1957a)

Acarinina soldadoensis (Brönnimann, 1952)

Acarinina strabocella (Loeblich \& Tappan, 1957)

Acarinina subsphaerica (Subbotina, 1947)

Acarinina wilcoxensis (Cushman \& Ponton, 1932)

Catapsydrax unicavus Bolli, Loeblich \& Tappan, 1957

Chiloguembelina crinita (Glaessner, 1937)

Chiloguembelina midwayensis (Cushman, 1940)

Chiloguembelina subtriangularis Beckmann, 1957

Chiloguembelina trinitatensis (Cushman \& Renz, 1942)

Chiloguembelina wilcoxensis (Cushman \& Ponton, 1932)

Eoglobigerina spiralis (Bolli, 1957a)

Globanomalina australiformis (Jenkins, 1965)

Globanomalina chapmani (Parr, 1938)

Globanomalina compressa (Plummer, 1926)

Globanomalina ehrenbergi (Bolli, 1957a)

Globanomalina ovalis Haque, 1956

Globanomalina pseudomenardii (Bolli, 1957a)

Guembelitrioides higginsi (Bolli, 1957b)

Guembelitrioides lozanoi (Colom, 1954)

Igorina albeari(Cushman \& Bermúdez, 1949)

Igorina broedermanni (Cushman \& Bermúdez, 1949)

Igorina pusilla (Bolli, 1957a)

Morozovella acuta (Toulmin, 1941)

Morozovella acutispira (Bolli \& Cita, 1960)

Morozovella aequa (Cushman \& Renz, 1942)

Morozovella angulata (White, 1928)

Morozovella apanthesma (Loeblich \& Tappan, 1957)

Morozovella aragonensis (Nuttall, 1930)

Morozovella caucasica (Glaessner, 1937)

Morozovella conicotruncata (Subbotina, 1947)

Morozovella densa (Cushman, 1925)

Morozovella dolobrata (Jenkins, 1971)

Morozovella formosa (Bolli, 1957a)

Morozovella gracilis (Bolli, 1957a)

Morozovella lensiformis (Subbotina, 1953)

Morozovella marginodentata (Subbotina, 1953)

Morozovella occlusa Loeblich \& Tappan, 1957)

Morozovella pasionensis (Bermúdez, 1961)

Morozovella spinulosa (Cushman, 1927)

Morozovella subbotinae (Morozova, 1939)

Morozovella velascoensis (Cushman, 1925)

Muricoglobigerina senni (Beckmann, 1953)

Parasubbotina pseudobulloides (Plummer, 1926)

Parasubbotina varianta (Subbotina, 1953)

Parasubbotina variospira (Belford, 1984)

Planorotalites pseudoscitula (Glaessner, 1937)

Praemurica inconstans (Subbotina, 1953)

Praemurica pseudoinconstans (Blow, 1979)

Praemurica uncinata (Bolli, 1957a)

Pseudohasterigina micra (Cole, 1927)

Pseudohasterigina wilcoxensis (Cushman \& Ponton, 1932)

Subbotina cancellata Blow, 1979

Subbotina cryptomphala (Glaessner, 1937)

Subbotina eocaena (Gümbel, 1868) emended Hagn \& Lindenberg, 1966

Subbotina frontosa (Subbotina, 1953)

Subbotina hagni (Gohrbandt, 1967)

Subbotina patagonica (Todd \& Kniker, 1952)

Subbotina triangularis (White, 1928)

Subbotina triloculinoides (Plummer, 1926)

Subbotina trivialis (Subbotina, 1953)

Subbotina velascoensis (Cushman, 1925)

Rectoguembelina cretacea Cushman, 1932

Zeauvigerina aegyptiaca Said \& Kenawy, 1956

Zeauvigerina waiparaensis (Jenkins, 1965) 


\section{REFERENCES}

Bains, S., Corfield, R.M. \& Norris, R.D. 1999. Mechanisms of climate warming at the end of the Paleocene. Science, 285: 724 727.

Barber, P.M. 1988. The Exmouth Plateau deep water frontier: a case history. In Purcell, P.G. \& Purcell, R.R. (Eds), The North West Shelf, Australia, 173-187. Proceedings of Petroleum Exploration Society of Australia, Symposium.

Beckmann, J.P. 1953. Die foraminiferen der Oceanic Formation (Eocaen-Oligocaen) von Barbados, Kleine Antillen. Eclogae Geologicae Helvetiae, 46: 301-412.

Beckmann, J.P. 1957. Chiloguembelina Loeblich and Tappan and related Foraminifera from the Lower Tertiary. In Loeblich, A.R. Jr (Ed.), Studies in Foraminifera. Bulletin of the United States National Museum, 215: 83-95.

Belford, D.J. 1984. Tertiary foraminifera and age of sediments, Ok Tedi-Wabag, Papua, New Guinea. Bulletin, Bureau of Mineral Resources, Geology and Geophysics, Australia, 216: 1-52.

Berggren, W.A. \& Norris, R.D. 1997. Biostratigraphy, phylogeny and systematics of Paleocene trochospiral planktic foraminifera. Micropaleontology, 43: suppl.1, 1-116.

Berggren, W.A., Kent, D.V., Swisher, I.I.I. \& Aubry, M.-P. 1995. Revised Cenozoic Geochronology and Chronostratigraphy. In Berggren, W.A., Kent, D.V., Aubry, M.-P. \& Hardenbol, J. (Eds), Geochronology, Time Scales and Global Stratigraphic Correlations. Society of Economic Palaeontologists and Mineralogists, Special Publication, 54: 129-212.

Bermúdez, P.J. 1961. Contribucion al estudio de las Globigerindea de la region Caribe-Antillana (Paleocene-Reciente). Boletin de Geologia (Venezuela), Pulicacion Especial (Congres Geologia Venezolano, 3d, Caracas, 1959, Mem. 3, 3: 1119-1393.

Billups, K., Ravelo, A.C. \& Zachos, J.C. 1998. Early Pliocene deep water circulation in the western equatorial Atlantic: implications for high-latitude climate change. Paleoceanography, 13: 84-95.

Blow, W.H. 1979. The Cainozoic Globigerinida. E.J. Brill, Leiden, The Netherlands.

Bolli, H.M. 1957a. The General Globigerina and Globorotalia in the Paleocene-Lower Eocene Lizard Springs Formation of Trinidad, B.W.I. In Loeblich, A.R. Jr (Ed.), Studies in Foraminifera. Bulletin of the United States National Museum, 215: 61-82.

Bolli, H.M. 1957b. Planktonic Foraminifera from the Eocene Navet and San Fernando Formations of Trinidad, B.W.I. In Loeblich, A.R. Jr (Ed.), Studies in Foraminifera. Bulletin of the United States National Museum, 215: 155-172.

Bolli, H.M. \& Cita, M.B. 1960. Globigerine e Globorotalie del Paleocene di Paderno d'Adda (Italia). Rivista Italiana di Paleontologia e Stratigrafia, 66: $361-408$.

Bolli, H.M., Loeblich, A.R. \& Tappan, H. 1957. Planktonic foraminifera families Hantkeninidae, Orbulinidae, Globorotaliidae and Globotruncanidae. Bulletin of the United States National Museum, 215: 3-50.

Brönnimann, P. 1952. Trinidad Paleocene and Lower Eocene Globigerinidae. Bulletins of American Paleontology, 34: 1-34.

Clarke, L.J. \& Jenkyns, H. 1999. New oxygen isotope evidence for long-term Cretaceous climatic change in the Southern Hemisphere. Geology, 27: 699-702.

Cole, W.S. 1927. A foraminiferal fauna from the Guayabal Formation in Mexico. Bulletin of American Paleontology, 14: 1-46.

Colom, G. 1954. Estudio de las biozonas con foraminiferos del Terciario de Alicante. Boletin Espana Instituto Geologico y Minero, 66: 1-279.

Corfield, R.M. 1994. Palaeocene oceans and climate: An isotopic perspective. Earth-Science Reviews, 37: 225-252.

Cushman, J.A. 1925. Some new foraminifera from the Velasco Shale of Mexico. Contributions from the Cushman Laboratory for Foraminiferal Research, 1: 18-23.

Cushman, J.A. 1927. New and interesting foraminifera from Mexico and Texas. Contributions from the Cushman Laboratory for Foraminiferal Research, 3: 111-119.

Cushman, J.A. 1932. Rectogüembelina, a new genus from the Cretaceous. Contributions from the Cushman Laboratory for Foraminiferal Research, 8: 4-7.
Cushman, J.A. 1940. Midway foraminifera from Alabama. Contributions from the Cushman Laboratory for Foraminiferal Research, 16: 51-73.

Cushman, J.A. \& Bermúdez, P.J. 1949. Some Cuban species of Globorotalia. Contributions from the Cushman Laboratory for Foraminiferal Research, 25: 26-45.

Cushman, J.A. \& Ponton, G.M. 1932. An Eocene foraminiferal fauna of Wilcox Age from Alabama. Contributions from the Cushman Laboratory for Foraminiferal Research, 8: 51-72.

Cushman, J.A. \& Renz, H.H. 1942. Eocene Midway foraminifera from Soldado Rock, Trinidad. Contributions from the Cushman Laboratory for Foraminiferal Research, 18: 1-14.

D'Hondt, S., Zachos, J.C. \& Schultz, G. 1994. Stable isotopic signals and photosymbiosis in late Paleocene planktic foraminifera. Paleobiology, 20: 391-406.

Dickens, G.R., Castillo, M.M. \& Walker, J.C.G. 1997. A blast of gas in the latest Paleocene: Simulating first-order effects of massive dissociation of methane hydrate. Geology, 25: 259-262.

Dickens, G.R. 2001. On the fate of past gas: What happens to methane released from a bacterially mediated gas hydrate capacitor. Geochemistry, Geophysics, Geosystems - G3, 2.

Exon, N.F., Haq, U. \& Von Rad, U. 1992. Exmouth Plateau revisited: scientific drilling and geological framework. Proceedings of Ocean Drilling Program, Scientific Results, 122: 3-20.

Finlay, H.J. 1939. New Zealand foraminifera: key species in stratigraphy, No. 2. Transaction of the Royal Society of New Zealand, 69: $89-128,327$.

Finlay, H.J. 1947. New Zealand foraminifera: key species in stratigraphy, No. 5. New Zealand Journal of Science and Technology, 28: 259-292.

Galbrun, B. 1992. Magnetostratigraphy of Upper Cretaceous and Lower Tertiary sediments Sites 761 and 762, Exmouth Plateau, Northwest Australia. Proceedings of Ocean Drilling Program, Scientific Results, 122: 699-716.

Glaessner, M.F. 1937a. Planktonische Foraminiferen aus der Kreide und dem Eozän und ihre stratigraphische Bedeutung. Studies in Micropaleontology, Moscow University Laboraties of Paleontology, $\mathbf{1}$ : 27-46.

Glaessner, M.F. 1937b. Studien über Foraminiferen aus der Kreide und dem Tertiär des Kaukasus. Problems in Paleontology, Moscow University Laboratory of Paleontology, 2-3: 349-410.

Gohrbandt, K.H.A. 1967. Some new planktonic foraminiferal species from the Austrian Eocene. Micropaleontology, 13: 319-326.

Gümbel, C.W. 1868. Beiträge zur Foraminiferenfauna der nordalpinen älteren Eocängebilde oder der Kressenberger Nummulitenschichten. Abhandlungen Bayerische Akademie der Wissenschafen, Math.-Physik Kl., 10: 579-730.

Hagn, H. \& Lindenberg, H.G. 1966. Revision of Globigerina (Subbotina) eocaena Gümbel from the Eocene of the Bavarian Alps. Akademy Nauk SSSR Voprosy Mikropaleontologii, 10: 342-350 (in Russian).

Haq, B.U., Hardenbol, J. \& Vail, P.R. 1987. Chronology of fluctuating sea level since the Triassic. Science, 235: 1156-1167.

Haque, A.F.M.M. 1956. The foraminifera of the Ranikot and the Laki of the Nammal Gorge, Salt Range. Memoirs of the Geological Survey of Pakistan, Palaeontologia Pakistanica, 1: 1-300.

Hornibrook, N. deB., Brazier, R.C. \& Strong, C.P. 1989. Manual of New Zealand Permian to Pleistocene foraminiferal biostratigraphy. New Zealand Geological Survey paleontological bulletin, 56: $1-175$.

Jenkins, D.G. 1965. Planktonic foraminiferal zones and new taxa from the Danian to lower Miocene of New Zealand. New Zealand Journal of Geology and Geophysics, 8: 1088-1126.

Jenkins, D.G. 1971. New Zealand Cenozoic planktonic foraminifera. New Zealand Geological Survey paleontological bulletin, 42: 1278.

Katz, M.E., Pak, D.K., Dickens, G.R. \& Miller, K.G. 1999. The source and fate of massive carbon input during the Latest Paleocene Thermal Maximum. Science, 286: 1531-1533.

Kelly, D.C., Bralower, T.J. \& Zachos, J.C. 1998. Evolutionary consequences of the latest Paleocene thermal maximum for tropical planktonic foraminifera. Palaeogeography, Palaeoclimatology, Palaeoecology, 141: 139-161. 
Kennett, J. 1982. Marine Geology. Prentice Hall, New Jersey.

Kennett, J.P. \& Stott, L.D. 1991. Abrupt deep-sea warming, palaeoceanographic changes and benthic extinctions at the end of the Paleocene. Nature, 353: 225-229.

Kump, L.R. \& Arthur, M.A. 1999. Interpreting carbon isotope excursions: carbonates and organic matter. Chemical Geology, 161: 181-198.

Loeblich, A.R. Jr \& Tappan, H. 1957. Planktonic foraminifera of Paleocene and early Eocene age from the gulf and Atlantic coastal plains. In Loeblich, A. R. Jr (Ed.), Studies in Foraminifera. Bulletin of the United States National Museum, 215: 173-198.

Martin, L.T. 1943. Eocene foraminifera from the Type Lodo Foramation Fresno County, California. Stanford University Publications, Geological Sciences, 3: 93-125.

McGowran, B. 1974. Foraminifera. Initial Reports of the Deep Sea Drilling Project, 22: 609-627.

Morozova, V.G. 1939. Foraminiferal superfamily Globigerinidea, superfam. nov. and some of its representatives. Akademy Nauk SSSR Doklady, 112: 1109-1111 (in Russian).

Norris, R.D. 1996. Symbiosis as an evolutionary innovation in the radiation of Paleocene planktic foraminifera. Paleobiology, 4: 461-480.

Norris, R.D. \& Röhl, U. 1999. Carbon cycling and chronology of climate warming during the Palaeocene/Eocene transition. Nature, 401: 775-778.

Nuttall, W.L.F. 1930. Eocene foraminifera from Mexico. Journal of Paleontology, 4: 271-293.

Olsson, R.K., Hemleben, C. \& Berggren, W. 1999. Atlas of Paleocene Planktonic Foraminifera. Smithsonian Contributions to Paleobiology, 85.

Pardo, A., Keller, G. \& Oberhänsli, H. 1999. Paleoecologic and Paleoceanographic evolution of the Tethyan realm during the Paleocene-Eocene transition. Journal of Foraminiferal Research, 29: $37-57$.

Parr, W.J. 1938. Upper Eocene foraminifera from the deep borings in King's Park, Perth, Western Australia. Journal of the Royal Society of Western Australia, 24: 69-101.

Plummer, H.J. 1927. 1926 Foraminifera of the Midway formation in Texas. University of Texas Bulletin, 2644: 1-206.

Said, R. \& Kenaway, A. 1956. Upper Cretaceous and Lower Tertiary foraminifera from Northern Sinai, Egypt. Micropaleontology, 2: 105-173.

Shackleton, N.J. \& Hall, M.A. 1990. Carbon isotope stratigraphy of bulk sediments, ODP sites 689 and 690, Maud Rise, Antarctica. Proceedings of the Ocean Drilling Program, Scientific Results, 113: 985-989.

Shipboard Scientific Party 1990. Site 762. Proceedings of the Ocean Drilling Program, Initial Reports, 122: 213-289.

Siesser, W. \& Bralower, T.J. 1992. Cenozoic calcareous nannofossil biostratigraphy on the Exmouth Plateau, Eastern Indian Ocean. Proceedings of Ocean Drilling Program, Scientific Results, 122: 601-631.

Stagg, H.M.J. \& Colwell, J.B. 1994. The structural foundations of the Northern Carnarvon Basin. In Purcell, P.G. \& Purcell, R.R. (Eds), The Sedimentary Basins of Western Australia. Proceedings of Petroleum Exploration Society of Australia, Symposium, 349364.

Subbotina, N.N. 1947. Foraminifers of the Danian and Paleogene deposits of the northern Caucasus. Macrofauna of the Caucasus Emba region and central Asia. Trudy VNIGRI, 39 (in Russian).

Subbotina, N.N. 1953. Fossil Foraminifers of the USSR: Globigerinidae, Hantkeninidae and Globorotaliidae Trudy VNIGRI, new series 76 (in Russian) Fossil foraminifera of the USSR; Globigerinidae, Hantkeninidae and Globorotaliidae (transl. E. Lees) Collet's Ltd, London and Wellingborough.

Thomas, E. \& Shackleton, N.J. 1996. The Paleocene-Eocene benthic foraminiferal extinction and stable isotope anomalies. In Knox, R.W.O'B., Corfield, R.M. \& Dunay, R.E. (Eds), Correlation of the Early Paleogene in Northwest Europe. Geological Society, London, Special Publications, 101: 401-441.

Thomas, E., Shackleton, N.J. \& Hall, M.A. 1992. DATA REPORT: Carbon isotope stratigraphy of Palaeogene bulk sediments, Hole 762C (Exmouth Plateau, Eastern Indian Ocean). Proceedings of Ocean Drilling Program, Scientific Results, 122: 897-901.

Todd, R. \& Kniker, H.T. 1952. An Eocene foraminiferal fauna from the Agua Fresca Shale of Maallanes Province, southernmost Chile. Special Publication of the Cushman Foundation for Foraminiferal Research, Washington DC, 1: 1-28.

Toulmin, L.D. 1941. Eocene smaller foraminifera from the Salt Mountain Limestone of Alabama. Journal of Paleontology, 15: $567-$ 611.

Toumarkine, M. 1981. Discussion de la validité de l'espèce Hantkenina aragonensis Nuttall, 1930. Description de Hantkenina nuttalli, n. sp. Cahiers de Micropaléontologie, Livre Jubilaire en l'honneur de Madame Y. Le Calvez, 4: 109-119.

Toumarkine, M. \& Luterbacher, H.-P. 1985. Paleocene and Eocene Planktic Foraminifer. In Bolli, H.M., Saunders, J.B. \& Perch-Nielsen, K. (Eds), Plankton Stratigraphy, 87-154. Cambridge University Press, Cambridge.

Veevers, J.J., Powell, C. McA. \& Roots, S.R. 1991. Review of seafloor spreading around Australia. I. Synthesis of the patterns of spreading. Australian Journal of Earth Sciences, 38: 373-389.

White, M.P. 1928a. Some Index Foraminifera of the Tampico Embayment of Mexico, Part I and Part II. Journal of Paleontology, 2: 177-215.

White, M.P. 1928b. Some Index Foraminifera of the Tampico Embayment of Mexico, Part I and Part II. Journal of Paleontology, 2: 280-317.

Wonders, A.A.H. 1992. Cretaceous planktonic foraminiferal biostratigraphy, Leg 122, Exmouth Plateau, Australia. Proceedings of Ocean Drilling Program, Scientific Results, 122: 587-599.

Zachiariasse, W.J. 1992. Neogene planktonic foraminifers from Sites 761 and 762 off northwest Australia. Proceedings of Ocean Drilling Program, Scientific Results, 122: 665-681.

Zachos, J.C., Lohmann, K.C., Walker, J.C.G. \& Wise, S.W. 1993. Abrupt climate change and transient climates during the Paleogene: a marine perspective. Journal of Geology, 101: 191-213.

Zachos, J., Pagani, M., Sloan, L., Thomas, E. \& Billups, K. 2001. Trends, rhythms, and aberrations in global climate $65 \mathrm{Ma}$ to present. Science, 292: 686-693. 